\title{
THE EFFECT OF MASSAGE THERAPY ON THE LEVEL OF TENSION HEADACHE PAIN
}

\author{
SRI MULYATI RAHAYU, R. SITI JUNDIAH, ERNA ISMAWATI
}

\author{
UNIVERSITAS BHAKTI KENCANA \\ INDONESIAN EDUCATION UNIVERSITY
}

EMAIL: sri.mulyati@bku.ac.id

\begin{abstract}
Tension headache is a head painful generally caused by contraction and tension of neck and head muscle. This painful usually happened to the employee of sewing department which sewing in sit position with low their neck repeatedly in long period, and its happen to reach the target which determined by the company. The purpose of the reseacrh is to find out the impact of massage therapy toward to the painful level of PT. Hansae Fashion World Wide employee 2015. This research uses quasi experiment with "one group pretest postest design" with 73 person which 43 person by using purposive sampling. The influence of massage therapy to the level of painful tension before massage therapy is 5.50, and after therapy become 3.30. The reduction is significant with P-Value $0.00<0.05$ and $\mathrm{Z}$ count $-5.805<\mathrm{Z}$ table -1.96 . So, $\mathrm{HO}$ rejected and $\mathrm{Ha}$ is accepted. Based on the researched, needed skill of massage therapy for medical in the clinic.
\end{abstract}

Keywords: Massage Therapy, The Level of Headache, Tension Headache

\section{INTRODUCTION}

Headache caused by muscle tension is a type of headache that is commonly found or felt. (Brunner \& Suddarth, 2002). Ordinary tension headache is felt pad a person who perform the activities are repeated with a time that is sufficiently long as factory workers.

Pain is interpreted differently between individuals, depending on the perception. Simply put, the pain can be defined as a sensation which is not fun either as a sensory and emotional associated with the presence of a damage tissues or factors other, so that people feel miserable, suffering will eventually interfere with daily activities, psychic, and others ( Asmadi, 2008 )

According to Vamolkot, De Hoon (2010) in Veranico (2012) tension type headache (Tension Headache) is the largest of the other types of headaches. Population-based studies used International Headache Society criteria for Migraine and Tension Type Headache (TTH), as well as Headache in General studies in which Chronic Daily Headache was also included. Globally, the percentage of the adult population with disorders headache $46 \%$, $1 \%$ Migraine, $42 \%$ Tension Type Headache and $3 \%$ unt uk Chronic daily headache (Stovner et al 2007). Efforts to reduce headaches can be done pharmacologically and nonpharmacologically. Non-pharmacologically, namely by means of massage, hot and cold compresses, and transcutaneous electrical nerve stimulation (TENS) are simple steps in order to reduce pain perception. This method causes the release of endophrine thereby blocking the transmission of pain stimuli (Potter \& Perry, 2006). 
Massage Therapy is a natural and traditional way to prevent disease (M. Ferry Wong, 2011). Massage therapy is a healing effort that is safe, effective, and without side effects, and can be done alone or with the help of an expert (Firdaus, 2011). Massage therapy is a manipulation of the tissue is soft, generally by using a hand, to stimulate and relax and reduce stress and anxiety (Craven \& Hirnle, 2002). Massage or massage can relieve stress and facilitate the pumping of oxygen that is refreshing to the brain. This is because the blood circulation is smooth due to dilated blood vessels due to warmth as an effect of the massage performed. Massage can cause the muscles to relax and reduce pressure (Iskandar Ali, 2010). Based on a preliminary study conducted at the clinic of PT Hansae Fashion World Wide Karawang, nursing staff reported that in a day there are approximately 40 people who come to the factory clinic, and 20 people who come with complaints of headaches which are dominated by tension headaches. namely 8 , which is dominated by employees of the factory part of sewing (menjah it). Because in the factory there are 500 people in the sewing section and this is the largest number of people in the sewing department .

It is also due to the work of sewing which is done in the position of sitting, with the position of his head down and do it continuously in long hours of work to meet the targets that have been set by the factory. In a time of one hour per person it is required to be able to sew 500 pieces of parts clothes. It 's what makes the employees of the plant have to work extra and could not take the time to stretch the neck muscles. If someone complains of being sick, the production of clothes can decrease from 500 peaces per hour to 400 peaces. The clinic says that they always provide pain relievers for their employees' complaints considering that there is very little time for the employee to stop sewing.

\section{METHOD}

The type of research used in this study is a quasi experiment, with the aim of knowing a symptom or effect that arises as a result of treatment (Notoatmodjo, 2010). Quasi experiments were conducted on research that provides treatment massage movements on the level of tension headaches headache, pain intensity was then measured before and after the massage therapy to determine the effect of massage therapy on the level of tension headaches headache.

The population in this study were employees of sewing factories who came to the clinic with complaints of tension headaches in one month, as many as 73 people. Sampling with purposive sampling technique, namely the collection of samples based on certain considerations made by the researchers themselves, based on the characteristics of the population that have been known previously (Notoatmodjo, 2010).

Inclusion Criteria:

1) Tension headache.

2) No history of hypertension.

3) Not taking analgesics / pain relievers .

4) Headache tension head pain caused by work

effects. Exclusion criteria :

1) Headache tension headaches with complications, such as work

accidents. Based on the above criteria, the sample used by the researcher

was 42 people.

The data were analyzed using the Wilcoxon Signed Rank Test formula to analyze the effect of massage therapy on the level of tension headaches.

The level of tension headaches is measured by using a 10-point pain intensity scale with explanatory words (Smeltzer, SC bare BG, 2002). By showing how many pain scales are being felt before and after massage therapy. Head pain level on the instrument it is not ny eri, pain mild, pain was, pain weight control, pain severe uncontrolled. While the instrument used in this massage therapy is SOP. 
Table 1 Frequency Distribution of Tension Headache Headache Levels Before Massage Therapy for Factory Employees Who Experience Tension Headache Headaches

\begin{tabular}{clcc}
\hline No. & Anxiety Level & amount & Percentage (\%) \\
\hline 1 & No Pain & 0 & 0 \\
2 & Mild pain & 0 & 0 \\
3 & Moderate pain & 36 & 86 \\
4 & Controlled severe pain & 6 & 14 \\
5 & Uncontrolled severe pain & 0 & 0 \\
\hline & Total & 42 & 100 \\
\hline
\end{tabular}

Table 2 Frequency Distribution of Tension Headache Headache Levels After Massage Therapy on Factory Employees Who Experience Tension Headache Headaches

\begin{tabular}{clcc}
\hline No. & \multicolumn{1}{c}{ Anxiety Level } & amount & Percentage (\%) \\
\hline 1 & No Pain & 0 & 0 \\
2 & Mild pain & 35 & 83 \\
3 & Moderate pain & 7 & 17 \\
4 & Controlled severe pain & 0 & 0 \\
5 & Uncontrolled severe pain & 0 & 0 \\
\hline & $\quad$ Total & 42 & 100 \\
\hline
\end{tabular}

Table 3 Effect of Massage Therapy on the Level of Tension Headache Pain

No. Median Anxiety Level $Z^{P \text {-value }}$

1 Before Massage Therapy 5.50

2 After Massage Therapy 3.00

$-5,8050.000$ 


\section{DISCUSSION}

\section{Level of Tension Headache Pain Before Doing Massage Therapy}

Based on table 1 above, it can be explained that the level of tension headaches before doing massage therapy, almost all of the respondents as many as 36 people (86\%) were at a moderate pain level, and very few respondents as many as 6 people $(14 \%)$ were at the pain level. weight controlled. Based on the research, the number of female factory employees who experience tension headaches is more than that of men. This is because in addition to activities that do originator of pain head on women over many of the men as hormones and periods of her menses. Women experiencing pain head due to hormone every month. It is caused by declining estrogen is naturally on the period of this.

Level of Tension Headache After Massage Therapy

Based on table 2 above, it can be explained that the level of tension head pain after massage therapy, almost all respondents as many as 35 people $(83 \%)$ are at a mild pain level, and very few respondents as many as 7 people $(17 \%)$ are at the pain level. moderate. Massage is a simple step in reducing pain perception. Massage can reduce pain levels but not relieve pain. Massage causes the release of endophrins

thus blocking the transmission of pain stimuli (Potter \& Perry, 2006). This is what makes the level of tension headaches decrease after massage.

The Effect of Massage Therapy on the Level of Tension Headache Pain

Based on the results of the Wilcoxon Signed-Rank Test statistical test, it was found that the median level of tension headaches prior to massage therapy was 5.50. And after massage therapy is done, the median level of tension headache is 3.00 , based on these results it can be seen that the median difference between before and after massage therapy is 2.50 .

The reduction in pain levels was significant based on the results of the Wilcoxon SignedRank Test statistical test because the $p$ value $(0.000)<0.05$. With this, there is the effect of massage therapy on the level of tension headaches headache before and after massage therapy. Then $\mathrm{HO}$ is rejected and $\mathrm{Ha}$ is accepted. This shows that there is an effect of massage therapy on the level of tension headaches.

In this study, there is an effect of massage therapy on the level of tension headaches, this is because by massage the muscles become more relaxed and relaxed and also improve blood circulation, so that nutrients and oxygen carried by the blood can optimally reach the brain and throughout the body. This allows energy to be channeled properly. In addition, with the smooth circulation of blood, the metabolism that occurs is aerobic metabolism, so that there is no accumulation of lactic acid which can cause pain. 


\section{CONCLUSION ON}

1. Almost all factory employees prior to the massage therapy were at moderate level of tension headaches (86\%).

2. Almost all factory employees after massage therapy were at the level of mild tension headaches $(83 \%)$.

3. There is an effect of massage therapy on the level of tension headaches in factory employees at PT. Hansae Fashion World Wide Karawang.

\section{REFERENCES}

[1] T. Hadiansyah, A. Pragholapati, and D. P. Aprianto, "Gambaran Stres Kerja Perawat Yang Bekerja di Unit Gawat Darurat,"vol. 7, no. 2, pp. 50-58, 2019.

[2] R. Muliani, A. Pragholapati, and I. P. Lestari, "Jurnal Kesehatan dr . Soebandi Mahasiswa Sarjana Keperawatan Tingkat Akhir,”vol. 8, no. 1, pp. 34-39, 2020.

[3]A. Pragholapati, U. Padjadaran, and F. Keperawatan, "PERAWAT YANG BEKERJA DI UNIT GAWAT DARURAT ( UGD) RUMAH SAKIT AL ISLAM ( RSAI ) BANDUNG THE CORRELATION OF RESILIENCY WITH NURSE 'S WORK STRESS IN EMERGENCY UNIT RUMAH SAKIT AL ISLAM ( RSAI ) BANDUNG,"2010.

[4] A. Pragholapati, "Hubungan masalah kesehatan jiwa dengan strategi koping seseorang yang mengalami perceraian di kota bandung,"2016.

[5] A. Pragholapati and W. Ulfitri, "Gambaran Mekanisme Coping pada Mahasiswa Program Studi Sarjana Keperawatan Tingkat IV yang Sedang Menghadapi Tugas Akhir di Sekolah Tinggi Ilmu Kesehatan X Bandung,"Humanit. (Jurnal Psikologi), vol. 3, no. 2, pp. 115-126, 2019. 
[6] A. Pragholapati, R. S. Oktapiani, and Efri Widianti, "Pengaruh Brain Gym Terhadap Tingkat Depresi Pada Lansia Di Balai Perlindungan Sosial Tresna Werdha Ciparay Bandung,"Sk. keperawatan, vol. 5, no. 2, pp. 128-146, 2019.

[7] A. Ariani et al., "INFORMATION COMMUNICATION TECHNOLOGY ( ICT ) IN MIDWIFERY EDUCATION ( A REVIEW OF THE LITERATURE ),"vol. 3, no. 1, pp. 20142017, 2019.

[8] A. Pragholapati and F. Munawaroh, "Resiliensi pada lansia,"J. Surya Muda, vol. 2, no. 1, pp. 1-8, 2020.

[9] A.Pragholapati, F. Munawaroh, Stik. Jenderal Achmad Yani, and Stik. Bhakti Kencana Bandung, "RESILIENSI PADA LANSIA,"ojs.stikesmuhkendal.ac.id, vol. 2, no. 1, p. 2020.

[10] A. Pragholapati, “COVID-19 IMPACT ON STUDENTS,"2020.

[11] A. Pragholapati et al., "TINGKAT KECEMASAN PADA PASIEN ANAK USIASEKOLAH (6-12 TAHUN) DI RUANG IGD RSUD MAJALAYA KABUPATEN BANDUNG ANXIETY LEVEL IN SCHOOL-AGE PATIENTS (6-12 YEARS) IN THE EMERGENCY ROOM AT MAJALAYA REGIONAL HOSPITAL BANDUNG REGENCY,"BMJ, vol. 6, pp. 1-7, 2019.

[12] A. Pragholapati, "RESILIENSI PADA KONDISI WABAH COVID-19,"2020.

[13] A. Pragholapati et al., "PENGARUH BRAIN GYM TERHADAP TINGKAT DEPRESI PADA LANSIA DI BALAI PERLINDUNGAN SOSIAL TRESNA WERDHA CIPARAY BANDUNG THE EFFECT OF BRAIN GYM TO THE LEVEL OF DEPRESSION IN GERIATRIC AT BALAI PERLINDUNGAN SOSIAL TRESNA WERDHA CIPARAY BANDUNG."

[14] J. Kesehatan dr Soebandi, R. Muliani, A. Pragholapati, and I. Permatasari Lestari, "Hubungan Tingkat Stres dengan Kejadian Sleep paralysis pada Mahasiswa Sarjana Keperawatan Tingkat Akhir,”J. Kesehat. dr. Soebandi, vol. 8, no. 1.

[15] A. Pragholapati, "Self-Efficacy Of Nurses During The Pandemic Covid-19,"no. May 2020, p. 2020.

[1] Pragholapati, A. (2020). Effect Of Progressive Muscle Relaxation Technique On Pain In Post Sectio caesarea. Jurnal Kesehatan dr. Soebandi, 8(2), 112-122.

[2] NURLIANAWATI, L., ARDIANA, F., \& PRAGHOLAPATI, A. GAMBARAN FUNGSI KOGNITIF PADA LANJUT USIA (LANSIA).

[3] Pragholapati, A., Muliani, R., Imam, H., \& Haryana, I. F. (2020). Effect of Socialization Group Activities Therapy: Sociodrama on Loneliness Level For Elderly at Panti Werdha Sosial Tresna and Pemeliharaan Taman Makam Pahlawan Ciparay Kabupaten Bandung. Jurnal Keperawatan Respati Yogyakarta, 7(3). 
[4] Pragholapati, A. (2020). PENGALAMAN SESEORANG YANG BERCERAI KARENA PERSELINGKUHAN DI KOTA BANDUNG: FENOMENOLOGI. Jurnal Surya Muda: IImu Keperawatan Dan IImu Kesehatan, 2(2), 66-75

[5] Pragholapati, A. (2020). PENGALAMAN SESEORANG YANG BERCERAI KARENA PERSELINGKUHAN DI KOTA BANDUNG: FENOMENOLOGI. Jurnal Surya Muda: IImu Keperawatan Dan IImu Kesehatan, 2(2), 66-75

[6] Pragholapati, A. (2020). Literature Review: Pengalaman Ayah yang Memiliki Bayi Prematur di NICU.

[7] Pragholapati, A. (2020). INTERPROFESSIONAL COLLABORATIVE PRACTICE (IPCP).

[8] Pragholapati, A., Yosef, I., \& Soemantri, I. (2020). The Correlation of Resilience With Nurses Work Stress In Emergency Unit Rumah Sakit Al Islam (RSAl) Bandung. Sorume Health Sciences Journal, 1(1), 9-18.

[9] Pragholapati, A. (2020). GAMBARAN SESEORANG YANG BERCERAI DI KOTA BANDUNG. Jurnal Skolastik Keperawatan, 6(1), 42-48.

[10] Pratama, A. S., Lestari, A. A., Yudianto, K., Megawati, S. W., \& Pragholapati, A. (2020). SUPERVISI KEPERAWATAN DI RUMAH SAKIT. Jurnal Keperawatan'Aisyiyah, 7(1), 55-62.

[11] Hadiansyah, T., \& Pragholapati, A. (2020). KECEMASAN KELUARGA DALAM MERAWAT KLIEN SKIZOFRENIA. Jurnal Keperawatan'Aisyiyah, 7(1), 25-29.

[12] Muliani, R., \& Pragholapati, A. (2020). Pengaruh Komunikasi Terapeutik Perawat terhadap Tingkat Kecemasan Keluarga Pasien Di Ruang Perawatan Intensif. Health Information: Jurnal Penelitian, 12(1), 63-75.

[13] Pragholapati, A., Septiani, D. D., \& Sudiyat, R. (2020). Parent Anxiety Levels In Hospitalization Children In RSUD Majalaya Kab. Bandung. Health Media, 1(2), 40-44.

[14] Pragholapati, A. (2020). DAMPAK PERCERAIAN DI INDONESIA: SYSTEMATIC LITERATURE REVIEW.

[15] Pragholapati, A. (2020). GOVERNANCE IN MENTAL HEALTH NURSING. PsyArXiv. June, 13.

[16] Ariani, A., Destyana, A., \& Pragholapati, A. (2020). GAMBARAN DUKUNGAN SUAMI TENTANG PROGRAM PERENCANAAN PERSALINAN DAN PENCEGAHAN KOMPLIKASI. Jurnal Maternitas Aisyah (JAMAN AISYAH), 1(2), 87-91.

[17] Rohayani, L., Inayah, I., Shoumi, A. S., \& Pragholapati, A. (2020). Pelayanan Prima Perawat Berdasarkan Persepsi Pasien di Ruang Rawat Inap Talaga Bodas (Penyakit Dalam Pria Kelas 3) Rumah Sakit Tingkat II 03.05. 01 Dustira Cimahi 2019. Journal Of Health Science (Jurnal IImu Kesehatan), 5(1), 42-46. 
[1], [2], [11]-[13], [3]-[10]

\section{REFERENCES}

[1] A. Pragholapati and W. Ulfitri, "Gambaran Mekanisme Coping pada Mahasiswa Program Studi Sarjana Keperawatan Tingkat IV yang Sedang Menghadapi Tugas Akhir di Sekolah Tinggi Ilmu Kesehatan X Bandung," Humanit. (Jurnal Psikologi), vol. 3, no. 2, pp. 115-126, 2019, doi: 10.28932/humanitas.v3i2.2168.

[2] R. Muliani, A. Pragholapati, and I. P. Lestari, "Jurnal Kesehatan dr . Soebandi Mahasiswa Sarjana Keperawatan Tingkat Akhir,” vol. 8, no. 1, pp. 34-39, 2020, doi: 10.36858/jkds.v8i1.159.

[3] A. Pragholapati, U. Padjadaran, and F. Keperawatan, "PERAWAT YANG BEKERJA DI UNIT GAWAT DARURAT ( UGD ) RUMAH SAKIT AL ISLAM ( RSAI ) BANDUNG THE CORRELATION OF RESILIENCY WITH NURSE' S WORK STRESS IN EMERGENCY UNIT RUMAH SAKIT AL ISLAM ( RSAI ) BANDUNG,” 2010.

[4] A. Ariani et al., "INFORMATION COMMUNICATION TECHNOLOGY ( ICT ) IN MIDWIFERY EDUCATION ( A REVIEW OF THE LITERATURE ),” vol. 3, no. 1, pp. 2014-2017, 2019.

[5] A. Pragholapati and F. Munawaroh, "Resiliensi pada lansia," J. Surya Muda, vol. 2, no. 1, pp. 1-8, 2020.

[6] A. Pragholapati, "Mental Health in pandemic," pp. 1-7, 2020.

[7] S. Tahun, D. I. Ruang, and I. G. D. Rsud, "Tingkat Kecemasan Pada Pasien Anak Usia Majalaya Kabupaten Bandung Anxiety Level in School-Age Patients ( 6-12 Years ) in the Emergency Room At Majalaya Regional Hospital Bandung Regency," vol. 6, no. 1, pp. 1-7, 2019.

[8] A. Pragholapati, "HUBUNGAN BULLYING DENGAN KEMAMPUAN SOSIAL PADA REMAJADI SMK X KOTA BANDUNG," vol. 9, no. 1, pp. 34-40, 2020.

[9] A. Pragholapati, R. S. Oktapiani, and Efri Widianti, "Pengaruh Brain Gym Terhadap Tingkat Depresi Pada Lansia Di Balai Perlindungan Sosial Tresna Werdha Ciparay Bandung," Sk. keperawatan, vol. 5, no. 2, pp. 128-146, 2019.

[10] T. Hadiansyah, A. Pragholapati, and D. P. Aprianto, "Gambaran Stres Kerja Perawat Yang Bekerja di Unit Gawat Darurat," vol. 7, no. 2, pp. 50-58, 2019.

[11] A. Pragholapati, "Hubungan masalah kesehatan jiwa dengan strategi koping seseorang yang mengalami perceraian di kota bandung," 2016.

[12] A. Pragholapati, "Self-Efficacy Of Nurses During The Pandemic Covid-19," no. May 2020, p. 2020.

[13] A. Pragholapati, "COVID-19 IMPACT ON STUDENTS," pp. 1-6, 2020. 